University of Michigan Law School

University of Michigan Law School Scholarship Repository

Articles

Faculty Scholarship

1917

\title{
The Patentability of a Mental Process
}

John B. Waite

University of Michigan Law School

Available at: https://repository.law.umich.edu/articles/1344

Follow this and additional works at: https://repository.law.umich.edu/articles

Part of the Common Law Commons, and the Intellectual Property Law Commons

\section{Recommended Citation}

Waite, John B. "The Patentability of a Mental Process." Mich. L. Rev. 15, no. 8 (1917): 660-4.

This Response or Comment is brought to you for free and open access by the Faculty Scholarship at University of Michigan Law School Scholarship Repository. It has been accepted for inclusion in Articles by an authorized administrator of University of Michigan Law School Scholarship Repository. For more information, please contact mlaw.repository@umich.edu. 
Tine Patentability of a Mental Process.-The fact of possession has been so correlated with the theory of property that it is difficult to dissociate ownership from the possibility of physical possession. One finds that the average lawyer, even though he may define a right in rem as a right enforcible against any person, is extremely apt, unless after especial thought, to explain that it is enforcible against anyone because it pertains to a thing capable of physical possession and control, a thing that could be actually sequestered from all other persons. Not at all infrequently the term property has been judicially stripped even of its significance of a right, and con- 
fined to the objective material thing to which the right might apply. As a matter of fact, comparatively few things have ever been legally recognized as the object of property which have not been tangible. The right to one's reputation, and, more lately recognized, the right to privacy, for instance, are rights in rem, although incapable of tangible possession. The right to have a contract performed without interference by a third party and, it has been said, the right created by assignment of a chose in action, are equally rights $i$ rem. These, and other res, are mere concepts, in no sense whatever corporeal, although the rights concerning them so appertain to the particular person in whose favor they exist as to be truly property rights, and correctly said to be owned by him. But the whole number of these is small compared to the quantity of tangible things which are the subject of property, and even these rights are not usually spoken of, even judicially, in terms of property, as are those pertaining to tangible things.

This difficulty in recognizing a mere mental concept, incapable of physical custody, as a proper subject of legal ownership, is quite evident in the law relating to patents for inventions. The Common Law recognized no property right whatever in an invention. It is possible that it did admit existence of a right in respect to the rem of an author's concepts, as formulated in words by him, but that right was so early covered by statute as to leave the state of the Common Law in some doubt. In respect to inventions, however, there is no doubt-one had no property right, as such, in his mental concept of a means for accomplishing a given result. So long as he kept his idea of means to the particular end locked in his own mind, it could not be legally dragged from him. Evan if he revealed it, in such a way that the recipient of the knowledge was pledged to secrecy, equity. would enjoin a breach of that pledge by the holder of the secret. But if the idea became known, in any way, its enjoyment was free to the public. The conceptor of the idea had no control over it whatever; he consequently had no more property in it than did the latest of those who had learned it. Any tangible thing in which he might embody the idea, being itself subject to control, was his property, just as would be any chattel which one might construct, but the idea embodied in the chattel was open to use by all the world who could find it out.

Any right in rem to the sole enjoyment of the idea depended altogether upon an express grant thereof by the sovereign, and still depends, in this country, wholly upon a grant of such right from the government. The statutes permitting such grants, and the patents granted thereunder, have been interpreted and construed by courts trained in the Common Law and accustomed to its assumptions. It is not suprising, therefore, to find occasionally evinced the feeling that the subject matter of a patent, that is, an "invention," ought to be something more than a mere concept of means, indeed must be a tangible thing of some sort. The very statute conveys this impression in directing the issue of a patent for an "art, machine, manufacture or composition of matter."

Fortunately for the undoubted purpose of the patent statutes, this has 
been confined to expression and not carried into actual decision. It has not been wholly innocuous, because of the confusion it appears to have caused between "invention" and "evidence of the existence of" a particular invention. But so far as actual decisions are concerned, and in all careful expression, it is unquestionably the concept of the means to the end which is the subject of the patented property, and not merely the particular tangible things which may be constructed in embodiment of the idea. Indeed, things which are so constructed by others than the patentee, however wrongfully it may be done, are not the property of the patentee and do not become so because of their infringing character.

Unless a patent is extremely narrow, the patentee's protection is not restricted to the particular machine or device he may describe. His monopoly includes all machines of the same type and purpose which, though different in substantial form, do not involve any inventive difference. These can not be called the "same" machine as the one described by the patent since they are obviously materially different, but, as they embody the same idea of means, they are called "equivalents." If it were the tangible machine which was patented, this breadth of protection could not follow. It can be predicated only on the fact that the invention protected is the idea of means embodied in the material means literally described.

A good illustration of the fact.that it is the idea which is patented, and not the substantial embodiment, is the case of Tilghman v. Proctor, I02 U. S. 707. The patentee in this case claimed nothing substantial at all, but said merely, "I claim, as my inverition, the manufacturing of fat acids and glycerine from fatty bodies by the action of water at a high temperature and pressure." In his description he did set out a particular tangible means by which this could be accomplished. The court held that his protection was not limited to the described means but coverad the accomplishing of the result by obviously different material aids. It named the invention a "process" or a "mode of acting," and distinguished it from a "machine" by -saying "The one [machine] is visible to the eye-an object of perpetual observation. The other is a conception of the mind, seen only by its effects when being executed or performed."

Practically all of the definitions likewise concede that "The invention itself is an intellectual process or operation," Phila. Etc. R. R. Co. v. Stimpson, I4 Pet. 448 , or in other more or less precise expression indicate that it is the mental concept, and not the tangible embodiment of it which really constitutes the subject of the patent. (The quoted definition is, of course, inexact to the extent that it attempts to express a "thing" in terms of an "act," but the thought contained in it is clearly that an invention is a concept.) It would be supererogatory to demonstrate further this fact.

An idea of means which is not capable of embodiment as an objective means has never, so far as the writer is aware, been the subject of an adjudicated patent. It is therefore an undecided question whether an invention which does not require tangible instrumentalities to effectuate the result desired is patentable. To argue that it is patentable would seem, it 
must be confessed, like opposing a merely conjured contradiction, were it not for the number of patent law experts who have expressed a belief that such an idea could not be subject of a patent.

It is difficult, though not impossible, to conceive of an idea of means which does not involve the use of tangible instrumentalities. It largely depends on what one admits to be the "instrumentalities." There has been published, apparently at the author's expense, an amusing pamphlet, unconsciously amusing, and rather pathetically so, called "The Bitter, Bitter Cry of Outcast Inventors." The author's plaint is the refusal of the British government to patent an invention of his, and the suggestion of various publishers, to whom he offered the exposition of his idea, that he rest and recuperate in the country. His concept was a system of shorthand. To utilize it, fifteen men sit in a row, with fifteen more behind them. When a speech to be reported is commenced, person number one in the rear row taps the shoulder of number one in the front row just as the first word of the speech is being uttered. At the utterance of the second word, person number two of the rear ranks taps the shoulder of person number two in the front rank. Thus each rear rank man taps the shoulder of the man in front of him, in rotation, as the consecutive words of the speech are delivered. The person so tapped writes the word being uttered as the signal is given. At the end of the speech, a compilation of all the written words becomes a verbatim report of the speech. Assuming, for the sake of the argument, that this concept involved inventive genius, would it be patentable?

Even if it were admitted to be patentable, it might be said actually to utilize substantive means, namely, the persons of the thirty men, to efrectuate its end, and therefore not to be conclusive of the issue. If one were to evolve a method for trisecting the angle, it is possible that the pencil and paper required-if only to present an unknown angle-might be called a substantive "means." Arithmeticians and mathematicians, however, are frequently evolving short-cuts to a desired end which involve purely mental processes, and which overwhelm the non-mathematical mind with astonished admiration at the rapidity with which the given result is reached. If one of these methods of arriving at the desired result were the creation of inventive genius-and surely the productions of mathematicians are more truly the result of something transcending mere trained skill, common to all their calling, than are many mechanical inventions-would it be patentable?

The only possible objection is in lingering vestige of the common feeling that property is physical. But when the Patent Law has been pressed to the point, it has invariably acted on the assumption that patented property is intangible. It is true that intangible property can not be "made," and it is loosely said-again the supposition of physical property-that it is not vendible, yet the patent statute gives an exclusive right to make, use and vend the invention. If making, using and vending were all necessary to constitute infringement, it is obvious that a mere mental process could not be infringed, and therefore was not presumably intended as the subject matter of a patent. But the phrase has been consistently interpreted as meaning make, 
use or vend. It is in nowise necessary that an infringer do all of the forhidden acts, the doing of any one of them is sufficient, and it does not follow that patentable invention must be capable of enjoyment or infringement in all three ways. Its susceptibility to "use" would surely be sufficient. There is nothing therefore in the wording of the statute to preclude the patenting of such a process for accomplishing a desired result.

No more is there any reason in law, as established extraneous to the patent decisions, why the inventor should not have an exclusive right to the use of such an invention, except the bald fact that the Common Law did not recognize a right in rem to any invention. It did recognize other intangible $r c s$, however, so that there was no legal impossibility in an intangible ambit for a property right. As respects inventions particularly, the Common $L_{\text {aw }}$ was changed by the statute. The logic of the change undoubtedly extends it to all inventions, whether they utilize tangible instrumentalities or not.

It is true that the exclusive right to such an invention might be extremely difficult to enforce, but the mere practical unsatisfactoriness of the remedy has never derogated the completeness of the right. Furthermore, it is not inconceivable that the exclusive right to use such an invention might have a very practicable value. If the means, the mental process, were one which could be used on the stage, for instance, to mystify audiences of those who were unacquainted with its ditails, the right to its use for such purposes might well be of considerable monetary value. "Whether it is the law that such a concept is patentable, only the Supreme Court can say. Till that tribunal has spoken, it is, like the presence or absence of the inventive quality, a matter of opinion. But it may be said of this, as a certain lecturer used to say of invention, "if there is no reason why it is not, it probably is." J. B. W. 